Published in: In Feminists and Queer Theorists Debate the Future of Critical Management Studies (Dialogues in Critical Management Studies, Volume 3). Emerald Publishing Limited, pp.129 - 153.

\title{
The Neoliberal Crisis: Alternative Organizing and Spaces of/for Feminist Solidarity
}

\author{
Maria Daskalaki \\ Roehampton University \\ Marianna Fotaki \\ University of Warwick
}

\begin{abstract}
Radical feminist theory and practice has actively questioned power relationships between men, women and people of color as a cornerstone of capitalist development since the 1970s while demonstrating the differential impact of such inequality generating structures and relationships on lives and bodies. Their argument about the process of social reproduction and, especially, the reproduction of labor-power both achieved through the dispossession of the female and (colonial) body and the expropriation of their work (Federici, 2004), is acutely relevant to the analysis of the consequences of the unfolding Global Financial Crisis. Yet the crisis can be a motivating force for changing the established power relations. Using three different cases studies of female initiatives aiming to counteract the imposition of neoliberal attack on their livelihoods in crisis stricken Greece, the chapter examines how the existing experience of feminist thinking and activism from within and outside of academia, can contribute to the cultivation of affective embodied relations, and building upon the idea of 'feminist solidarity' (Mohanty, 2003), in addressing the challenges of the crisis and post-crisis policies.
\end{abstract}

Key words: feminism, global financial crisis, austerity, affect, body, solidarity, activism

To cite: Maria Daskalaki, Marianna Fotaki, "The Neoliberal Crisis: Alternative Organizing and Spaces of/for Feminist Solidarity" In Feminists and Queer Theorists Debate the Future of Critical Management Studies. Published online: 11 Apr 2017; 129-153.

Permanent link to this document: http://dx.doi.org/10.1108/S2046-607220160000003012 


\section{Introduction}

The ongoing 2008 Global Financial Crisis (GFC) is multidimensional and, critically, has affected not only the financial spheres of activity across the world but also political and social institutions and communities. A number of countries have been directly affected by what around the end of 2008 became apparent: technological transformation of finance, liberalization of financial markets, imbalance between capital accumulation and borrowing as well as the lack of proper supervision in financial practices, which have all contributed to severe multilevel crises. Several years since its outset, the effects of the US-born global financial crisis, which spread to the Eurozone and affected most EU countries, continue to deepen. There is a widespread recognition that this is the effect of misguided austerity policies (Stiglitz, 2010), causing severe social inequalities, high rates of unemployment and unrest. Such developments demanded immediate and substantial socio-economic restructuring and alternative forms of cooperation and exchange (Gibson-Graham, 2008; 2013) to address the most damaging impact of these policies on the most vulnerable sections of the population. Yet, elected political parties throughout Europe have failed to effectively deal with financial meltdown and by applying austerity measures such as privatizations, cutting down public spending and reducing benefits and pay for both public and private sector employees, instead seek to find short-term solutions. In addition to the GFC we therefore face multiple crises of governance and democracy.

Yet the crisis occupies a central role in critical thought and politics because it is generally regarded as a motivating force for changing the established relations of power. Without idealizing and romanticizing it, it is important to acknowledge its disruptive potential for transformation because crisis represents a threshold between what is and what is not-yet (Amsler, 2012). For such a transformative potential to be realized we must acknowledge the differential distribution of risks the austerity policies pose in diverse geographical locales and how they affect various social groups and different people. Southern Europe and particularly Greece, the context of the current study, has been severely hit by the GFC and austerity politics with crucially high rates of unemployment. Thus, if we are to creatively engage with events of crisis and alternatives to neoliberalism and austerity, we ought to consider the contexts within which they are embedded (Castells et al., 2012). Prior work on critical geography (see for example Harvey, 2012) has suggested that the local and the global are not defined in terms of physical geography or territory but exist simultaneously and constitute each other. It is then the links and the relationships between the local and the global that are foregrounded, and these links are conceptual, material, temporal and contextual.

Critically, the effects of these austerity measures are unevenly distributed within Greece, 
reflecting inequalities among geographical locations, between women and men, locals and migrants as well as secure and precarious workers, with many of these inequalities preceding the current crisis (Karamessini, 2013; Vaiou, 2014). Dispossession and impoverishment affects women in disproportionately large numbers in times of crisis. Marxist autonomist feminist Silvia Federici argues that recognizing the connection between capitalism and the gendered division of labour is a test case for feminist theory. Federici's thesis about the appropriation of the reproductive life-giving creative work by turning people into disposable labour and social buffers during the crisis is useful for understanding current developments. Indeed, it is the labor of social reproduction that typically forms a buffer in times of crisis, as households take on additional work to substitute services they can no longer afford to buy and/or the state no longer provides:

'Overall, there has been a transfer of financial risk over a number of years, away from the banking sector to nonbanking sectors [...]. This dispersion of risk has made the financial system more resilient, not the least because the household sector is acting more as a 'shock absorber of the last resort' (IMF, 2005).

Thus, while the emergence of alternatives in the context of crisis can be studied as a project of re-configuring socio-spatial relations (Harvey, 2012), the household cannot be neglected any more as a crucial site of power struggle, as it is the space that sustains and, at the same time, resists capitalism. Focusing on this, feminist research has been especially critical of the World Bank's Structural Adjustment Programmes (SAPs) introduced into many countries in the 'Global South' through the 1980s (see Elson, 1993, 1995; see also Roberts, 2015; Pollard, 2012), and their implicit, normalized, gendered assumptions and uneven outcomes. According to this work, the macro-economic policies have often assumed an elastic endurance on the part of those affected such that "the hidden "equilibrating factor" [that] is women's ability to absorb the shocks of stabilization programmes, through more work and "making do" on limited incomes' (Elson, 1993: 241).

The gendered roles and identities of women as mothers and housewives have been reinforced by their increasing care responsibilities in the context of the withdrawal of more socialized forms of welfare provision. Macro-economic approaches to the crisis have unveiled certain aspects of the crisis while deemed others as peripheral, showing that 'austerity bites, [yet] never equally' (Peck, 2012: 629); women (in different regions), as embodied subjects, have been affected considerably more by unemployment, precarious living, salary and pension cuts, poverty and deprivation or shrinking social rights and mounting everyday violence 
(Vaiou, 2014). But as Federici (2004) argues, the strategy of cheapening the costs of labor, which has been re-launched in the face of every major capitalist crisis, hides the exploitation of women and embodied others (e.g. the colonial subjects), which is at the heart of the capitalist development. Although the patriarchy predates it, almost every capitalist crisis is unmistakeably fought over and through women's souls and bodies. Capitalism was established on brutal exploitation of women and colonial others (Mies, 1986) but 'the degradation of women [and their bodies] are necessary conditions for the existence of capitalism in all times' (Federici, 2004: 13).

Patriarchal discourses and practices are actively deployed in the service of managing the crisis directly targeting women through the feminization of poverty. Women's experience and responses to crisis are therefore bound to be qualitatively different and perhaps more radical. In this context, it is important to explore the gendered aspects of the crisis and the activist movements that are developing as a response to neoliberal order though many of such organized actions aiming to counteract the onslaught on women's lives and livelihoods may not identify themselves as explicitly feminist. Yet, we must consider the potential turn to the cultivation of affective relations, and building upon the idea of 'feminist solidarity' (Mohanty, 2003), in addressing the challenges of the crisis and post-crisis policies. It is worth exploring how the feminist academic activism can act as a source of support to these movements and what we can learn from these mobilizations as gender researchers. Specifically we would like to highlight the need to research (i) the conditions under which women's participation in movements which are not explicitly feminist or focused on specifically gendered issues lead to a change in power relations; (ii) the ways through which activist-academic approaches can unveil the constitutive role of women in social movement organizing and particularly the implications of their participation for the movements' organizing processes, values and practices; and finally, (iii) the role of embodiment, affect and emotion in the study of social movements and political mobilization.

This chapter therefore discusses the neoliberal crisis and how spaces of feminist solidarity affect the organization of alternatives by introducing literature that originates from two fields, feminist/economic geography and feminist theory (applied in social movement analysis). Particularly, we will explore some of the ways through which social movement scholarship contributes to a feminist analysis of activism, which in conditions of crisis, assists in developing a fuller understanding of the affective and embodied dimensions of alternative organizational forms and spaces for resistance. Although this is a theoretical paper that attempts to formulate a research agenda for feminist activism in crisis, we will also provide some examples of activist organizing in Greece to provide an illustration for our arguments. 
First, we discuss feminist approaches in relation to alternative organizing. After, we present the context of the study and explore the landscape of feminist solidarities as these arise in the context of Greece. Doing that, we put the body at the centre of our analysis in an attempt to reflect on how feminist activism can be employed during a neoliberal crisis to contest capitalist enclosures and patriarchal erasures. We then attempt to build the conditions, within broader activist movements, through which women can develop a praxis that opens spaces for affectivity and embodied re-articulation of socio-spatial relationships as a way of resisting such policies. Finally, we identify potential areas for future empirical research.

\section{Feminist theory and post-2008 alternative organizing}

It has been suggested that there is a resurgence of feminist organizing and feminist theorizing at the heart of a range of social movements today (Eschle and Maiguashca, 2010). Prior research has raised questions about how well new social movements can defend women from the worst effects of neoliberalism and about women's role in the struggle for a postneoliberal, post-patriarchal world. It also suggests that women 'continue to resist, in both familiar and more inventive ways, attempting in so doing to redefine the nature of feminism and of politics and to challenge patriarchal and neoliberal orthodoxies' (Motta et al., 2011: 1). Nevertheless, though women help with the work of regime change (see for example, Nicaragua women's struggle - Molyneux, 1985; more recent armed struggle of Kurdish women against ISIL in Northern Syria and Iraq in Rojava - Tax, 2016, Dirik, 2014), feminists identified a tendency to fade gender equality from social change agendas. As Bhattacharjya, Birchall, Caro, Kelleher \& Sahasranaman (2013: 280) suggest, practitioners and activists trying to achieve practical change on the ground still experience strong resistance within the "deep structure" (Rao and Kelleher, 2005: 64) of movements and affiliated organizations'.

More recently, research suggested that Occupy's focus on wealth obscured other differences based on gender, class, race, and sexual orientation. Also, in projecting itself as leaderless, the movement lost the chance to reflect on its own internal dynamics.

\footnotetext{
'The tensions of how a movement frames its arguments to include women, people of color, disabled people, and LGBTI people came to the surface. Some people felt these tensions were never sufficiently considered, or ignored altogether. For others, Occupy presented an opportunity to highlight these factors' (Bhattacharjya, Birchall, Caro, Kelleher \& Sahasranaman, 2013: 287).
} 
This partly reflects historical contradictions within the left-leaning movements of Marxist origins that see women's oppression as the manifestation of the capitalist system which would be resolved if the class system could be overcome that disregards patriarchy as prior to capitalism and the liberation of women as a prerequisite for liberation from all forms of oppression that militant feminists have espoused (Karcher, 2016). Accordingly, feminists have drawn attention to, among other things, 'the tacit assumptions that the default activist was male (and indeed white, able-bodied and heterosexual); the tendency to consider gender as at best an add-on variable rather than a constitutive feature of social movements; a disregard for the role of embodiment, affect and emotion in the study of social movements and political mobilization' (Dean and Aune, 2015: 376). Gliding over and disregarding the embodied aspect of politics also underplays the ways in which the neoliberal order has been imposed and maintained through the gendered mechanization of the female and/or feminine body, its exploitation and commodification under capitalism, and its objectification as a site of reproduction. As Federici (2004) explains: 'the redefinition of productive and reproductive tasks and male-female relations' [during the transition to capitalism], 'both realized with the maximum of violence and state intervention, leaving no doubt as the constructed character of sexual roles in capitalist society' (p. 12). The mechanisms through which this has been achieved firstly describe the reprivatization of reproduction and the rise of (especially women's) domestic labour. Second, growing labour market insecurity, unstable employment and declining real wages, which led to the normalization of substandard working conditions, the casualization of work, low-wage jobs and precarious employment and as a result the decline of the family wage model. Third, by blurring the once separate areas of production and reproduction as increasingly overlapping, home work constitutes an important family strategy to counteract the neoliberal economic crisis. Finally, the neoliberal gender order has been reinforced through global trends towards both the feminization of poverty and transnational migrations (Bakker, 2003). This is for instance evidenced in the gendered migration of millions of women from the Global South as well as Eastern Europe to the West who desire to escape poverty and lack of opportunities in their own countries. They take up jobs in cleaning, care and prostitution in the West where they find that escape from one form of oppression only opens the door to another form of oppression (O'Healy, 2007). Globalization and transmigration thus aptly demonstrates how historical established forms of exploitation that women of colour, non-Western women in postcolonial settings and poor women in the West have experienced are often interrelated and co-implicated in the production of new inequalities while simultaneously creating new modes of organizing, hybrid cultures and identities (Marciniak, Imre and O'Healy, 2007). Furthermore, not only is the 'feminization of poverty' a direct consequence of globalization but also the high level of 
violence against women today may be explained by the gendered division of labour globally where the main work available to men in many dispossessed area of the developing world is in the violence generating industry - working as soldier, security or jail guard (see Federici and Sitrin, 2016 referring to the work of a sociologist, Jules Falquet).

Building on the aforementioned studies in this chapter, we want to discuss the relationship of feminist theory and social movement organizing and particularly, what feminist theory can offer alternative organizing after the 2008 neoliberal crisis. The context of our discussion is the recent fiscal crisis and the accompanying austerity measures implemented in many European countries, which led to the curtailment of public services and the rise of various forms of social enterprise, self-help and solidarity economies (Castells et al, 2012; Daskalaki et al. 2015; Fotaki, 2015). In particular, in Greece, which provides some of the empirical illustrations we use here, many spontaneous initiatives sprung up in response to the crisis and austerity-induced reductions in services. These include social enterprises with truly collaborative and radical arrangements as well as workers cooperatives and solidarity movements. Such initiatives, often driven by necessity, give rise to value-driven alternatives including the re-appearance of the co-operative movement (Kokkinidis, 2014), worker-owned enterprises and the emergence of entirely new fields with socially transformative potentialities (see also Daskalaki, Sotiropoulou and Fotaki, under review).

Nevertheless, the majority of these studies have focused on the workplace, the state and on representational conceptualizations of the political, marginalizing women and leaving contemporary women's resistances outside of political considerations. In contrast, women's activism requires a radical expansion of what politics is and where it occurs, in ways that encompass the everyday, the private and the digital world of work (Talcott and Collins, 2012; $\mathrm{Ng}$ and Toupin, 2013). Thus, there is a need for engagement with such political forms that could reconfigure the composition, character and implications of political struggle and social transformation, in a ways that resolve the crisis of patriarchy and neoliberal models upon which current forms of capitalism are built. This can be achieved for instance by exploring other ways of structuring reproduction or thinking about both the inherently embodied nature of finance and the specific ways in which 'Transnational Business Feminism' agendas (see for example, Roberts, 2012) operate to produce, or at times to disappear, bodies. We thus want to look closer on the significance of women's involvement observed in these alternative organizations and provide an activist feminist framing of the crisis and alternative organizational forms. Academic activist feminism might also provide the political situatedness of feminist struggles and the consideration of historical continuities and discontinuities in which these are located (Fernandes, 2013). Crucial in this context is the 
truthful representation of various forms of struggle (including militancy and armed struggle) that women and feminists have engaged in over time accounting for important differences between feminist movements and women's participation in anti-capitalist resistance. For instance, Karcher explains that women armed groups operating in Germany in the 1970s did not have a feminist background or agenda: 'Like many other women who joined armed leftist struggles, the female militants of the RAF wanted to be equal to their male comrades' unlike the other militant all-female group ZORA, which 'took up central themes in German women's movements, including sexual objectification, trafficking in women, and transnational solidarity' (Karcher, 2016: 5).

In the current context of neoliberal crisis we consider it essential to concentrate on an activist feminist approach that examines the entire activity of the people who engage with alternative organizational forms taking on a new meaning, but also concentrates on the transformative potential of women's mobilization in terms of altering the existing power relations propagated through the neoliberal paradigm. Our aim is to examine feminist activism, embodied in the organization of alternatives, which expresses the will to resolve the crisis of patriarchy and neo-liberal models upon which current forms of capitalism are built by exploring other ways of structuring reproduction. This is because the expansive politicization process has implications for how women's bodies are experienced and lived. As Harvey (2000: 105) explains, the differential production of bodies takes place as they are 'marked by different physical productive capacities and qualities according to history, geography, culture, and tradition', reducing race, ethnicity, age and gender markers to descriptions of what particular kind of labor people are able to do (see also Roberts, 2015). Already Marx was attentive to the ways in which capital is inscribed on the bodies and in the flesh of laborers, documenting as he did how long hours of work, unregulated environment, and dangerous working conditions produced tired, diseased, maimed, unhealthy, over worked and stunted bodies. Clearly, 'the location of our laboring bodies as well as their biophysical attributes are crucially important in determining how individuals and groups take part in the process of social reproduction' (Ferguson, 2008: 51). Yet it was autonomist Marxist feminists who developed a full theory of the embodied labour focusing on how women's exploitation played a central function in the process of capitalist accumulation, insofar as women have been the producers and reproducers of the most essential capitalist commodity: labor-power, in the 1970s (see Dalla Costa, 1974; James, 1973, Fortunati, 1995 quoted in Federici, 2004).

In the following section, we focus on embodied forms of resistance to the imposed the neoliberal austerity in crisis-stricken Greece, and employ three examples of women's alternative organizing; (i) women's cooperatives (a café/social centre called Beaver and 
member of Workers Cooperatives Networks of Athens); (ii) the women's participation in S.O.S Halkidiki, a movement against gold mining in Northern Greece; (iii) an all-female sacked cleaner movement in order to explore how the feminist thinking contributes to the emergence of a solidarity-based, networked social movements that are organized around the affective and embodied dimensions of alternative forms.

\section{Politicization of the Body during the (Greek) Crisis: Organizing Alternatives}

\section{The Context}

Greece's economic crisis erupted when the Global Financial Crisis hit US banks in 2008 and spread to European banks. The events exposed structural weaknesses of Greek economy such as low competiveness, high borrowing and widespread tax evasion but the crisis has deepened since the 'bail out' of 2010. The country underwent the sixth consecutive year of economic contraction in 2015, with its economy shrinking by 26\% between 2008 and 2015. Unemployment has more than tripled, from $7.7 \%$ in 2008 to $24.3 \%$ in 2012 , and long-term unemployment reached 14.4\% (Simou and Koutsogeorgou, 2014). Greece, at this point in time, has the highest rates of youth unemployment in the EU. 'Women working in so-called informal work, or in home-based enterprises or piece-rate work - low paid and usually lacking any non-wage benefits - are especially vulnerable to economic downturns' (Pollard, 2012: 7). In May 2014 the total \% of unemployment was 27.2 and for females under 25 years of age, unemployment has reached $59.4 \%^{1}$. In 2009 , women's unemployment was $12 \%$ and men's around $5.0 \%$. By 2013, these figures reached $31.0 \%$ and $24.7 \%$, respectively. The figures look more dramatic among women under 25 years of age: unemployment went up from $36.6 \%$ in 2009 to $65.0 \%$ in 2013 ; the respective figures for men rose from $12.1 \%$ to $52 \%$ (ELSTAT, Labour Force Surveys, 2009, 2013). At the same time, the suicide rate in Greece has increased 26.5 per cent from 377 in 2010 to 477 in 2011, and has increased by 104.4 per cent in the case of women.

Along with austerity cuts to cover budget deficits, the withdrawal of public services intensifies pressures on households, with deeply gendered implications. As services that assist those with caring roles and provide for those in need (childcare, social care services etc.) are cut, 'women will by default be the ones to 'pick up the tab' and fill the gaps left in provision...withdrawing vital support risks adding to women's unpaid and informal caring roles and further entrenching the already unequal distribution of labour. The knock-on effect 
will be to limit women's opportunities to work and engage fully in public and political life including in positions of power and influence' (Fawcett Society, 2012).

The financial crisis has contributed to the differential production of bodies with a particular significance to differences stemming from the differential valuation of labor, contributing to a further commodification of women's bodily capacities as they are projected as 'untapped resources' in need of exploitation by (Western) capital (Roberts, 2015). Thus, attention is drawn to the specific ways in which the socially and historically constructed valuation of one's reproductive capacities also produces difference along the same lines. This is precisely the point made by feminist geographers, who have convincingly argued that the globalizing tendencies of capitalism have not led to a simple convergence of experiences but rather to the creation of various 'continuities and disjunctures, including in the production of gender subjectivities and bodies' (Roberts, 2015: 115).

Here we present three different case studies of women organizing, all of which have emerged in the context of crisis. They illustrate the different forms of resistance to the neoliberal onslaught on women and the hollowing of women's lives and all demonstrate the potentiality for women to develop their autonomous spaces for political struggle and devising strategies for social transformation. These studies represent different forms of autonomous organization that crisis has forced upon them but also perhaps prove how, by pooling their resources, women might create more collective forms of response and resistance to guarantee their own livelihood and survival of their communities. Such forms of resistance emerging from their immediate concerns perhaps open a room for inclusivity, collaborations and alliance forging with other social groups threatened with exclusion and targeted with austerity policies such as the growing number of new poor, unemployed and immigrants in Greece and other European countries that are severely hit by the GFC and the accompanying austerity policies.

\section{The Beaver Café}

'In January 2012', the women of Beaver café state, 'we had a spontaneous idea about the creation of a space run by women, that would be open to people and groups who find it otherwise difficult to "belong" somewhere, and that would be also a fun hangout for us to meet. It was that concept that brought all of us together and finally came to fruition in September $2013^{\prime 2}$. Linked through their participation in other initiatives and collective feminist groups and collective kitchens, the Beaver's eight co-founders support that

'the de-education from the capitalist mode of labor relations and the cultivation of solidarity, 
comradeship and mutual understanding, as opposed to individualism, the rationalism of achieving maximum individual benefit, and individual solutions...the need of creating horizontal networks of cooperation, of abolishing the misconceived notion of competitiveness, steering clear from the concept of masters/bosses and other similar calamities' (Beaver, Women's Cooperative).

As they explain, in the activities of the cooperative, priority is given to women's creativity (artistic, scientific or other) and raising awareness events related to women's issues, including the construction of women's identities (cis gender, transgender, gender variant). The activities will also include the dissemination of the idea of collectivism through building solidarity networks with similar autonomous groups. These 'autonomous geographies' (Pickerill and Chatterton, 2006) have both a material and symbolic role to play in fostering affective relations by bringing forward alternative forms of civic life (see Image 1: an exhibition of a female young artist in the café area of Beaver). It is the bodies and labor of women that constitute the heart of this struggle for alternatives: their gendered bodies are the key to exposing and resisting the processes of colonization and capitalist exploitation.

Insert Image 1 about here

Prior research, with very few exceptions (Vaiou, 2014) has yet to concentrate upon the role of women in the contemporary, growing cooperative movement in Greece. A recent mapping of grassroots alternatives has shown that there was a $70 \%$ increase in the recorded numbers of alternative organizations in Greece within a single year, from 2013 to 2014 (Omikron Project, $2015)^{3}$. By 2015, we can locate over 3391 alternatives across the country that stretch from the creative sectors to agriculture and from health to information technology, media and communications, eco-communes and occupied spaces, with some of them connected through their association with various solidarity initiatives (Enallaktikos, 2015) ${ }^{4}$. These solidarity initiatives operate like networks that bring together various alternatives movements and affect resistance spaces where new subjectivities can emerge. Beaver is a member of the Workers Cooperatives Network of Athens and one of the first women-only initiatives that has been established recently in Greece. Many of the democratic practices and process-oriented aspects of feminism appear to be embedded into the decision-making processes of some of these solidarity initiatives. For example, the principles of non-hierarchy, democratic participation, and the notion of the personal being political all emerge as crucial in co-constructing new forms of what Boggs (2000) calls 'placed-based civic activism':

'Place consciousness . . . encourages us to come together around common, local experiences and organize around our hopes for the future of our communities and cities. While global capitalism doesn't give a damn about the people or the natural environment of any particular place because it can always move on to other people and other places, place-based civic 
activism is concerned about the health and safety of people and places' (Boggs 2000: 19).

Across various social movements and alternative organizations that our study included, we have witnessed a significant presence of women who not only set up alternatives but also transform significantly the relationships and values of the groups that they join. Since women are central to the life of neighborhood and communities they assume key positions in these struggles. It is then that the lives, experiences, and struggles of these women demystify capitalism in its sexual dimension, providing productive pathways towards theorizing and enacting new resistance potentialities. This indicates that for the women to exercise their politics they need an autonomous space to build new relations of and take control of their bodies and lives (Federici and Sitrin, 2016). Perspectives on identity as an embodied practice that is both fluid and processual as well as affectively and discursively co-produced (Fotaki, Metcalfe and Harding, 2014) could be also drawn to explore the potential for resistance and transformation that such fluid contextuality implies. This is particularly important in the globalized context since as Braidotti explains, 'advanced capitalism is a difference engine-a multiplier of de-territorialized differences, which are packaged and marketed under the labels of 'new, hybrid and multiple or multicultural identities' (Braidotti, 2006: 134 quotation marks in the original).

\section{Anti-mining movements in Skouries Chalkidiki}

Until recently, the picturesque hilltops in the Northern Greek peninsula of Halkidiki were covered with 400-year-old oak and beech tree forests. The Canadian mining company Eldorado Gold has now clear-cut an old growth forest to build Greece's first and biggest open-pit and underground gold mine. 'With its acquisition of the Canadian European Goldfields in 2012 and the Australian Glory Resources in 2013, Eldorado Gold now owns all the gold projects in Greece that are currently in development or in operation. It has a welldeveloped tax avoidance structure using 12 Dutch mailbox companies and various subsidiaries in Barbados, as well as in the British Virgin Islands and Cayman Islands' (Hartlief et al., 2015:10). Independent scientific reports predict that the Skouries mine will cause permanent environmental damage.

As a response, numerous protests were held in the region as well as in Athens and Thessaloniki, gathering thousands of people, with the most notable the one held in Thessaloniki in March 2013 (an estimated 15,000 people gathered at the Canadian consulate to protest against the mining operations). Several solidarity events followed this, and almost one year later, in 2014, the women of Skouries chained themselves to the main entrance gate 
of Eldorado Gold's mining site (See Image 2), an action that was supported by solidarity supporters worldwide:

\footnotetext{
'Our solidarity is with those brave women who are once again putting their bodies on the line at the gates of Eldorado Gold. They have faced state violence, judicial persecution, and other anti-democratic measures (including the latest law about to be voted on in the Greek parliament, which is an outrage.) They are fighting to save their water and their land. History is on their side' (Klein and Lewis, 2014).
}

Insert Image 2 about here

For feminist activist movements, the body can be an element in the articulation of postcapitalist arrangements that aim to counteract the effects of neoliberal crisis and defend life. The use of female bodies 'against the oppressive and coercive elements of the state in protests, and as means to protect the community, turns the body into a site of resistance and pride' (Motta et al., 2011: 24). As research on women's resistance in Argentina has indicated, multiple forms of injustice converge in and are contested through women's bodies, stressing the bodily scars of neoliberal globalization and the role of bodies as tools and vehicles of political action (Sutton, 2010). Bodies have been used by activists as political 'arguments' (DeLucca, 1999) or 'text' (Peterson 2001), symbols that convey political meanings. By calling attention to their own bodies, like the women at Skouries have done, activists construct 'compelling images' where the body becomes an 'argumentative resource' (DeLucca, 1999). Bodies, thus, are used during neoliberal crisis and austerity politics to contest patriarchal erasures and to build the conditions, within broader activist movements, through which women can communicate their experiences, and develop a praxis that opens spaces for affectivity and embodied re-articulation of socio-spatial relationships.

\section{Sacked cleaners camping outside of the Ministry of Finance}

A group of 30 cleaners of the Greek Ministry of Finance attended the first European Parliament plenary session in Strasbourg in September 2014, exactly one year after being fired. Since then, and until 2015, they protested daily outside the ministry offices, and by creating a permanent camping protest space (see Image 3), they became another symbol of resistance against the EU's austerity policies. The image of middle aged women being sacked from the Ministry of Finance, the enforcer of the Troika imposed austerity policies, was a particularly vivid picture of the injustices of the neoliberal order that for many is now synonymous with socializing the risk for the rich while letting the most vulnerable 'compete' 
in the market place in order to provide their service efficiently (this was encapsulated by the then Minister of Modernization, a Harvard-educated scion of a political family and product of nepotism co-implicated in bribe giving affair by Siemens Kyriakos Mistotakis ${ }^{5}$,, who asked sacked cleaners to form a company and bid for cleaning contracts himself from the ministry.

An international solidarity movement to support the Greek cleaners has also developed including the Belgian trade union FTGB, the CGT of France, the country's general confederation of labour, and in the UK, the Trades Union Congress (TUC). All supported a demonstration organised by the Greece Solidarity Campaign outside the Hellenic Centre in London. The call of the cleaning women in fight for their rights stated ${ }^{6}$ :

\footnotetext{
'As we belong to the lower strata of the working class and we are women, they thought we would be an easy target and the weakest link. But together with thousands of other redundant workers we fight against the Greek Government and Troika's measures that crush our lives and lead us to utter poverty. We continue our fight and shall not give up until we are vindicated with all the peoples in Europe, we struggle to defeat the policies that impoverish us, together we can!'.
}

Insert Image 3 about here

Indeed power relations and social hierarchies are imposed upon socially differentiated bodies 'whose concrete particularities become the source of their social, political, economic, institutional and cultural exclusion and marginalization [...]; racial hierarchies, gender orders and heteronormativity are corporal practices 'that are mobilized as physical markers of differences, and which support an uneven geography of exploitation, oppression and discrimination actively engaged in body formation' (Rioux, 2014: 8). In our case, the sacked cleaners, set up a camp outside the Finance Ministry offices, staying there for months, day and night, in order to claim their right to work, they urged citizens, unions, women's organizations, young people and others, to join their struggle. Along with their daily protests, when they stated that 'history is written through disobedience', they also participated in other social movements (such as the Caravan for Struggle and Solidarity) and social kitchens (like 'the other human'). Similar to the Argentinian poner el cuerpo, the cleaners' struggle indicated togetherness, engaging other bodies in the project of creating social change, of building power together from the bottom up. Accordingly, poner el cuerpo as a practice of resistance is not an individual task but 'a collective, embodied process that sprouts solidarity and valuable knowledge' (Sutton, 2010: 143). 
Soon after the Syriza party won the elections, Alexis Tsipras announced the reinstatement of the cleaning women at Greece's finance ministry. This was translated by the international press as the first anti-austerity decision enforced by his government (WSJ, 11 ${ }^{\text {th }}$ of May, $2015)^{7}$. It was a symbolic act that aimed to further strengthen the social democratic political identity of the party with voters but was not followed by an anti-austerity government policy. In fact the Syriza government continued the enforcement of a neoliberal agenda that demands widespread privatisation of public assets, pay and pension cuts, and tax rises for the already disadvantaged and crushing of autonomous spaces and social movements (for example, the self-organized refugee squat 'Orfanotrofio' in Thessaloniki). Therefore, the decision to hire the cleaners back to their initial posts, and later transfer some of them to other public sector positions, was a strategy of appropriation of the women's struggle that eroded their solidarity ties with other struggles and movements in Greece and elsewhere. Choosing to constitute the cleaners as the most vulnerable, the neoliberal machine 'invested the state structures with the paternalistic obligation to facilitate the achievement of feminist goals' (Butler, 2015: 141): Syriza distributed vulnerability unequally by rendering the cleaners more vulnerable than other social groups affected by austerity, and became the government that responds and cares for women's struggles, effectively by naturalizing relations of inequality. Yet, as Butler (2015: 70) proposes in Notes towards a performative theory of assembly, 'if the allocation of right to one group is instrumentalized for the disenfranchisement of basic entitlements to another, then the group entitled is surely obligated to refuse the terms on which political and legal recognition and rights are being given'.

Nevertheless, the struggle of the cleaners contributed to relations of solidarity beyond the spaces their struggles were performed, and mobilized a series of alliances that demonstrate that potentiality and impotentiality are inherently linked: they are part of the same flow of subjectivity that circulates from one configuration to another, or in Deleuzo-Guattarian terms, from one territory to another. Indeed, bodies are not self-enclosed entities (Deleuze, 1992); they are formed and lived in relation to conditions, which, though outside, are still part of the body itself; what Butler calls the 'social modality of the body' (Butler, 2015: 153). The example of the cleaners, similar to women's continuing struggle in Skouries, shows that, the act of exposing bodies in public space constitutes activist feminism as an embodied struggle and places sociality and affect in the centre of building feminist solidarities relations.

Accordingly, transnational solidarity building is essential for it enables us better understand what is to be a mobile and precarious worker in translocal late capitalism where none can feel safe, insulated or disconnected from global networks of power and culture. Building 
transnational solidarity greatly depends on women, gays, antiracist and other alternative forces, which, as Braidotti (2011) argues, with their 'leaky bodies' (Grosz, 1994), occupy ideal positions to reassert the power of the embodied flesh - what she describes as 'wetware'. This transformative process 'requires alternative figurations to express the kind of internally contradictory multifaceted subjects we have become [...] i.e. alternative representations and social locations for the kind of hybrid, sexualized nomadic subjects we are becoming' (Braidotti, 2011: 13).

\section{Discussion and the way forward}

In this chapter, we wanted to initiate a discussion that brings together activist feminist approaches with acts of resistance and solidarity as evidence of emerging forms of postcapitalist organizing. We drew on some examples of women's organizing in Greece to show that approaches, which connect the body with practices of organizing and resistance, can enrich our understandings and provide a starting point away from dominant discourse/s towards more alternative and collective ways out of the crisis. In line with Silvia Fedrici's theory we do not suggest or conceive of women's liberation as a 'return to the body' but argue for turning to women's body capacity to 'subvert the degraded image of femininity, which has been constructed through the identification of women with nature, matter, and corporeality' and 'to unbury what male control of our corporeal reality has suffocated' (p. 18). The power of the feminist "discourse on the body," is, as Federici says, 'about changing or re-signifying a signifier for a field of reproductive activities that have been appropriated by men and the state, and turned into an instrument for the production of labor-power (with all that this entails in terms of sexual rules and regulations, aesthetic canons, and punishments)' (ibid.). Both are essential preconditions for overcoming the fundamental alienation of the body - which for Federici will only cease with the ending of the work-discipline that defines it.

Nevertheless, the materialization of the body in space is an essential means for political action as Judith Butler (2011) argues drawing on Hannah Arendt's work, The Human Condition (1958). As Butler explains, for Arendt 'all political action requires the "space of appearance" but she also claims that "the "true" space then lies "between the people" which means that as much as any action takes place somewhere located, it also establishes a space which belongs properly to alliance itself' (Butler, 2011). Quoting Arendt, she further elucidates why this alliance is not tied to its location. 'In fact, alliance brings about its own location, highly transposable. She writes: "action and speech create a space between the participants which 
can find its proper location almost anywhere and anytime"'(Arendt, 1958: 198)'. This suggests that in all the cases discussed, 'occupying' space matters in so far as it involves creation of relational spaces where alliances can be forged and cultivated as a means of political struggle, that is, when the political importance of such events surpass our own individual self which is just there, located in this particular space, in a specific moment in time. As Butler has been arguing for some time now this is because:

'We are in this way, even as located, always elsewhere, constituted in a sociality that exceeds us. This establishes our exposure and our precarity, the ways in which we depend on political and social institutions to persist' (Butler, 2011).

Capitalism reproduces its immanent limits on a broader and more comprehensive scale and, in contrast to other social structures, constantly deterritorializes subjectivity (Deleuze and Guattari, 1977: 239). This process of deterritorialization, as the example of the Greek cleaners shows, seems to be related to 'lines of death and destruction' (Deleuze and Guattari, 1987: 508), which create subjectivities unable to realise their potentia (Braidotti, 2006). Yet, being conscious of one's impotentiality in relation to capital and power can be an active gesture of not engaging with the hegemonic capitalist and/or phallogocentric discourse (Sharpe, 2014: 38). In other words, understanding that active impotentiality can be sometimes more helpful than an ideological potentiality connected to the hegemonic narrative of performance (Sharpe, 2014: 41), might help engage in lines of flight bringing about actual emancipatory potentialities.

The role of affect as site of producing, reproducing and resignifying subjectivities, socialities and power relations must be duly emphasized. Affect permits us to re-form our subjectivities and intersubjective ways we relate with others in the world through constant exposure to power flows we shape and subject ourselves to. The potential for transforming power relations through affective attachments always entails the possibility of having to cope with what Brennan calls 'negative affects' (Brennan, 2004: 22) while the gendering potential of any affective encounter going beyond or besides of a subject involves a possibility of stifling the emergence of new subjectivities. In terms of political practice, the focus on affective labour might unwittingly contribute to blurring the lines that feminists had established in order to dispense with the separation between the gendering of the reproductive and productive labor (Federici, 2011, 2012).

Following this discussion, we propose a research agenda that focuses on three levels: First, future empirical research can explore the conditions under which women's participation in 
movements which are not explicitly feminist or focused on specifically gendered issues lead to a change in power relations. Experiences of women from other parts of the world who participated in similar activities to the ones that we describe briefly in here could be the subject. For instance, in anti-mining campaigns we seek to use the concept of resilience to better understand the position of women activists and the challenges they face (Jenkins and Rondón, 2015). As the authors indicate, ideas around 'resilience' enable us to frame women anti-mining activists as empowered actors without excluding men as important actors in these conflicts, but specifically to contribute to 'a growing literature concerned with the gendered particularities of resilience in diverse social contexts' (Lenette et al., 2012 quoted in Jenkins and Rondón, 2015). Transnational feminist solidarity approaches offer a potentially fruitful lens for addressing some of these issues as it connects the macro and micro levels of gender analysis helping us understand how the creation of particular identities is inextricably interwoven with power relations situated in place and time. As Braidotti puts it 'the historical era of globalization is the meeting ground on which sameness and otherness or centre and periphery confront each other and redefine their inter-relation' (Braidotti, 2006: 136). More importantly, globalization changes the roles of the former 'others' of modernity, namely women (along with natives and natural or earth others), turning them into powerful sites of social and discursive transformation (ibid).

Second, in times of rising discontent and resistance to neoliberal capitalism, activist-academic approaches can unveil the constitutive role of women in social movement organizing and particularly, the role of embodiment, affect and emotion in the study of social movements and political mobilization. Such a perspective could help further understanding of how power structures are distributed across gender, class, ethnicity and sexuality by, for instance, elucidating the ways in which individuals identify with the given power structures, how they support and resist them through affective mechanisms and creative appropriation (Fotaki and Harding, 2016). In particular, addressing how wider political and economic transformations affecting modes of work and production in organizations would help us consider the impact of transnational forces on individual bodies and subjectivities.

Despite the fact that there has been an increased interest in the study of alternative organizational formations (see Parker et al., 2014), women's bodies are still missing from recent conceptualizations of post-capitalist imaginaries in the field of critical management studies. Although the organizational structures of these alternative formations relies on equality, horizontally and inclusivity to fulfill their democratic, autonomous and egalitarian values, these movements, and the academics/researchers/activists studying them, will need to 
pay closer attention to the transformative values and socio-spatialities that can bring about new nomadic subjectivities. According to Braidotti (2006), the nomadic subject is

\footnotetext{
'an in-between: a folding-in of external influences and a simultaneous unfolding-outwards of affects. A mobile entity, in space and time, and also an enfleshed kind of memory, this subject is in-process but is also capable of lasting through sets of discontinuous variations, while remaining extra-ordinarily faithful to itself' (Braidotti, 2006: 135).
}

Therefore, queering alternatives (see related work by Parker, 2002; Rumens, 2016) is a way to challenge the 'unstated masculinism' of prior work on social movements and alternative organizational formations (Mohanty, 2003) as well as provide potentially more fertile ground for organizing, by building an affirmative feminist practice through translocal subjectivities.

As activist academics, studying alternative organizations and social transformation, we need to reflect on the need to embed struggles for reimagining the commons with a wider struggle for 'nomadic sustainable ethics' (Braidotti, 2011: 348). As Braidotti (2011) stresses, this struggle does not aim at mastery but at a transformation that puts the active back into activism as an ethical and a political project which will destabilize the autonomous subject in favour of liminal, dynamic, contingent and embodied subjectivities (Daskalaki, et al., 2016). Thus, we invite future work to explore the role of activist feminist ethnography as part of this ethical and political project as well as the possibilities and challenges that exist for feminist writing in a historical moment characterized by neoliberal crisis and post-neoliberal imaginaries. Feminist writing is the body inside and outside at the same time; it is i/rational, embodied, it proceeds elliptically and tentatively, in a fractured style, with the voices of others wound about the voice of the author (Cixous and Calle-Grubberm, 1997; see also work on embodied writing as a feminine alternative to the disembodied masculine; Höpfl, 2000; Fotaki, Metcalfe and Harding, 2014; Phillips, Pullen and Rhodes, 2014; Pullen, 2006; Pullen et al., 2016). Overall, feminist analysis has the capacity to address the manifold challenges of our time such as inequality, otherness and environmental destruction, not only by bringing in empirical evidence form how different resistance movements achieve these goals in practice but also offer support to these resistance activities while providing the continuity and transformative perspective in feminist struggle.

\section{References}

Amsler, S. (2012) Learning at the edge:Troublesome knowledge, public pedagogies and critical research. In: Teaching in Public, March 2012, University of Lincoln.

Arendt, H. (1958) The Human Condition. Chicago: Chicago University Press. 
Bakker, I. (2003) Neo-liberal governance and the reprivatization of social reproduction: Social provisioning and shifting gender orders. In Power, production and social reproduction UK: Palgrave Macmillan, pp. 66-82.

Boggs, C. (2000) The end of politics: Corporate power and the decline of the public sphere. New York: Guilford Press.

Braidotti, R. (2006) The ethics of becoming imperceptible. In C. Boundas (ed). Deleuze and

Philosophy. Edinburgh: Edinburgh University Press, pp. 133-159.

Braidotti, R. (2011) Nomadic theory: the portable Rosi Braidotti. Columbia University Press.

Brennan, T. (2004) The Transmission of Affect. Ithaca; London: Cornell University Press.

Bhattacharjya, M., Birchall , J., Caro, P., Kelleher D. and Sahasranaman, V. (2013) Why gender matters in activism: feminism and social justice movements. Gender and development, 21, 2: 277-293.

Bruff, I. (2013). The body in capitalist conditions of existence: A foundational materialist approach. In A. Cameron et al. (eds.), Body/State. Farnham: Ashgate, pp. 67- 83.

Butler, J. (2001) Bodies in Alliance and the Politics of the Street. http://www.eipcp.net/transversal/1011/butler/en. Published September 2011.

Butler, J. (2015) Notes Toward a Performative Theory of Assembly. U.S.A: Harvard University Press.

Castells, M., Caraça, J., \& Cardoso, G. (2012) Aftermath: The cultures of the economic crisis. Oxford: Oxford University Press.

Cixous, H. and Calle-Gruber, M. (1997). Rootprints: Memory and life writing. London, England: Routledge.

Dalla Costa, M. (1974) The Power of Women and the Subversion of the Community, Bristol, England: Falling Wall Press.

Daskalaki, M., Butler, C. and Petrovic, J. (2016) Somewhere in-between: Narratives of Place, Identity and Translocal Work, Journal of Management Inquiry, 25(2): 184-198.

Dean, J. and Aune, K. (2015) Feminism resurgent? Mapping contemporary feminist activisms in Europe. Social Movement Studies, 14: 4, 375-395.

Deleuze, G. and Guattari, F. (1977) Anti-Oedipus: Capitalism and Schizophrenia. New York: Viking Press.

Deleuze, G. and F. Guattari (1987) A Thousand Plateaus: Capitalism and Schizophrenia. Minneapolis: University of Minnesota Press.

Deleuze, G. (1992) 'Postscript on the Societies of Control', October, 59(Winter): 3-7.

De Lucca , KM (1999) The body rhetoric of earth first!, ACT UP, and Queer Nation. DeLuca, Kevin Michael.Argumentation and Advocacy; 36, 1, Argumentation and Advocacy, 36,1 (Summer): 9-21. 
Dirik, D. (2014) Western fascination with 'badass' Kurdish women. Aljazeera, October 29, 2014. Accessed March 18, 2015, at http:// www.aljazeera.com/indepth/opinion/2014/10/ western-fascination-with-badas-20141021124 10527736.html.

ELSTAT, Labour Force Surveys (2009) Monthly results. Available: www statistics.gr

ELSTAT, Labour Force Surveys (2013) Monthly results. Available: www.statistics.gr

Elson D (1993) Gender-aware analysis and development economics. Journal of International Development 5: 237-247.

Elson D (1995) Gender awareness in modelling structural adjustment. World Development, 23: $1851-1868$.

Eschle, C. and Maiguashca, B. (2010) Making feminist sense of the global justice movement, Lanham: Rowman and Littlefield.

Federici, S. (2004) Caliban and the Witch. Brooklyn: Autonomedia (reprint from 2004 edition).

Federici, S. (2011) On affective labor. In Cognitive Capitalism, Education, and Digital Labor, ed. by M. Peters. New York: Peter Lang

Federici, S. (2012) The reproduction of labor power in the global economy and the unfinished feminist revolution (2008)." In Revolution at Point Zero: Housework, Reproduction, and Feminist Struggle, 91-111. Oakland, CA; Brooklyn, NY; London: PM Press.

Federici, S. and Sitrin, M. (2016) Social reproduction: Between the wage and the commons, Roarmag August, 2016, Issue Two https://roarmag.org/magazine/social-reproductionbetween-the-wage-and-the-commons/

Ferguson, S. (2008) Canadian contributions to social reproduction feminism, race and embodied labor. Race, Gender \& Class, 15: 42-57.

Fernandes, L. (2013) Transnational Feminism in the United States. Knowledge, Ethics, Power. New York University Press: New York and London.

Fortunati, L. (1995) The Arcane of Reproduction: Housework, Prostitution, Labor and Capital. New York: Autonomedia.

Fotaki, M. and Harding, N. (2016) Gender and the Organization. Routledge.

Fotaki, M. (2015) Co-Production under the financial crisis and austerity: A means of democratizing public services or a race to the bottom? Journal of Management Inquiry, 24: 433-438,

Fotaki, M., Metcalfe, B. and Harding, N. (2014) Writing materiality into organization theory. Human Relations, 67(10): 1239-63.

Fawcett Society (2012) Policy Briefing: The Impact of Austerity on Women. http://www.fawcettsociety.org.uk/wp-content/uploads/2013/02/The-Impact-of-Austerityon-Women-19th-March-2012.pdf 
Grosz, E. (1994) Volatile Bodies: Towards a Corporeal Feminism. Bloomington: Indiana University Press.

Gibson-Graham, J. K., (2008) Diverse economies: performative practices for 'other worlds'. Progress in Human Geography, 32, 613-632.

Gibson-Graham, J. K., Cameron, J. \& Healy, S. (2013). Take back the economy: An ethical guide for transforming our communities. Minneapolis: University of Minnesota Press

Hadjimichalis, C. (2011) Uneven geographical development and socio-spatial justice and solidarity: European regions after the 2009 financial crisis. European Urban and Regional Studies, 18(2): 254-274.

Harvey, D. (2012) Rebel Cities: From the Right to the City to the Urban Revolution.

Harvey, D. (2000) Spaces of hope (Vol. 7). University of California Press.

Höpfl, H. (2000) The suffering mother and the miserable son: Organizing women and organizing women's writing. Gender, Work and Organization, 7:2, 98-105.

Hartlief, I. McGauran, K. Roos van Os, Römgens, Indra (2015) Fool's Gold: How Canadian firm Eldorado Gold destroys the Greek environment and dodges tax through Dutch mailbox companies. Amsterdam: Centre for Research on Multinational Corporations.

James, S. (1975) Sex, Race and Class. Bristol: Falling Wall Press.

Jenkins, K. and Rondón, G. (2015) 'Eventually the mine will come': women anti-mining activists' everyday resilience in opposing resource extraction in the Andes. Gender \& Development, 23(3): 415-431.

International Monetary Fund (2005) Global Financial Stability Report, Household Balance Sheets, Market Developments and Issues. Monetary and Capital Markets Department.

Karamessini M (2013) Structural crisis and adjustment in Greece. Social regression and the challenge for gender equality. In Karamessini M and Rubery J (eds) Women and Austerity. The economic crisis and the future for gender equality. London: Routledge, pp. 165-185.

Karcher, K (2016) Women in leftist armed struggle. Ed. by N. A. Naples. The Wiley Blackwell Encyclopedia of Gender and Sexuality Studies, First Edition. pp. 733-739.

Katz, C. (2001) On the grounds of globalization: A topography for feminist political engagement. Signs: Journal of Women in Culture and Society, 26(4): 1213-1234.

Lenette, C., Brough, M. and Cox, L. (2012) Everyday resilience: narratives of single refugee women with children. Qualitative Social Work 12(5): 637-653.

McDowell, L. (2006). Reconfigurations of gender and class relations. Antipode, 38(4 ): 825850.

McNally, D. (2001) Bodies of Meaning: Studies on Language, Labor, and Liberation. New York: SUNY Press.

Mies, M. (1986) Patriarchy and Accumulation On a World Scale. London: Zed Books. 
Mohanty, C. (2003) 'Under Western eyes’ Revisited: Feminist solidarity through anticapitalist struggles. Signs, 28(2) (Winter): 499-535.

Molyneux, M. (1985) Mobilization without emancipation? Women's interests, the state, and revolution in Nicaragua. Feminist studies, 11(2), 227-254.

Motta, S., Flesher Fominaya, C., Eschle, C. and Cox, L. (2011) Feminism, women's movements and women in movement (Editorial) Interface special issue Interface: a journal for and about social movements, 3(2): $1-32$.

Nagar, R. Lawson, V., McDowell, L. and Hanson, S. (2002) Locating globalization: Feminist (re)readings of the subjects and spaces of globalization. Economic Geography 78(3): 257284.

Ng, E., \& Toupin, S. (2013) Feminist and queer practices in the online and offline activism of Occupy Wall Street. Networking Knowledge: Journal of the MeCCSA Postgraduate Network, 6(3).

Orzeck, R. (2007) What does not kill you: Historical materialism and the body. Environment and Planning D, 25(3): 496-514.

Parker, M. (2002) Queering management and organization. Gender, Work \& Organization, $9,2,146-66$.

Parker, M., Cheney, G., Fournier, V. and Land, C. (2014) The question of organization: A manifesto for alternatives. Ephemera, 14, 623-638.

Peck, J. (2012) Austerity urbanism: American cities under extreme economy. City 16 (6): $626-655$.

Peterson, A. (2001) The Militant Body and Political Communication: The Medialization of Violence. In Contemporary Political Protest: Essays on Political Militancy. Aldershot: Ashgate, pp. 69-101.

Phillips, M., Pullen, A., and Rhodes, C. (2014) Writing organization as gendered practice: Interrupting the libidinal economy. Organization Studies, 35: 3, 313-333.

Pickerill, J., \& Chatterton, P. (2006) Notes towards autonomous geographies: creation, resistance and self-management as survival tactics. Progress in human geography, 30(6), 730-746.

Pollard, J. (2012) Gendering capital: Financial crisis, financialization and (an agenda for) economic geography, Progress in Human Geography, 1-21

Pullen, A. (2006). Gendering the research self: social practice and corporeal multiplicity in the writing of organizational research. Gender, Work \& Organization, 13: 3, 277-298.

Pullen, A., Thanem T., Tyler, M., Wallenberg, L. (2016) Sexual Politics, Organizational Practices: Interrogating Queer Theory, Work and Organization, Special Issue, January 23(1): $1-87$. 
Rao, A., \& Kelleher, D. (2005) Is there life after gender mainstreaming?. Gender \& Development, 13(2), 57-69.

Rankin, K. (2013) A critical geography of poverty finance. Third World Quarterly, 34(4): $547-568$.

Rioux, S. (2014) Embodied contradictions: Capitalism, social reproduction and body formation. Women's Studies International Forum, 48: 194-202.

Roberts, A. (2015) Gender, financial deepening and the production of embodied finance: Towards a critical feminist analysis. Global Society, 29, 1: 107-127.

Rumens, N. (2016) Towards queering the business school: A research agenda for advancing lesbian, gay, bisexual and trans perspectives and issues. Gender, Work \& Organization, 23(1), 36-51.

Sharpe, S. (2014) 'Potentiality and impotentiality in J. K. Gibson-Graham', Rethinking Marxism, 26 (1): 27-43.

Simou, E. and Koutsogeorgou, E. (2014) Effects of the economic crisis on health and healthcare in Greece in the literature from 2009 to 2013: A systematic review. Health Policy, 115: 111-119.

Stiglitz, J. (2010) The financial crisis of 2007/2008 and its macro-economic consequences. In Time for a Visible Hand: Lessons from the 2008 World Financial Crisis, S. GriffithJones, J.A. Ocampo, and J.E. Stiglitz, eds. Oxford: Oxford University Press, pp. 19-49.

Tax, M. (2016) The Road Unforeseen. Women Fighting the Islamic State. New York: Bellevue Literary Press.

Sutton, B. (2010) Bodies in crisis: Culture, violence, and women's resistance in neoliberal Argentina. Rutgers University Press.

Talcott, M., \& Collins, D. (2012) Building a Complex and Emancipatory Unity: Documenting Decolonial Feminist Interventions within the Occupy Movement. Feminist Studies, 38(2), 485-506.

Vaiou, D. (2014) Tracing aspects of the Greek crisis in Athens. Putting women in the picture. European Urban and Regional Studies 18(2): 254-274.

\section{Notes}

\footnotetext{
${ }^{1} \mathrm{http} / / /$ countryeconomy.com/unemployment/greece?dr=2014-05

${ }^{2} \mathrm{http} / / /$ beavercafe.blogspot.gr/2013/11/p-margin-bottom-0.html

${ }^{3} \mathrm{http}: / /$ omikronproject.gr/grassroots

${ }^{4}$ http://www.enallaktikos.gr/kg15el_diktya-allileggyis.html
} 
${ }^{5} \mathrm{http}: / / \mathrm{www}$.thepressproject.gr/article/55649/Arms-scandal-goes-prime-minister-time--Former-PMMitsotakis-implicated

${ }^{6} \mathrm{http}: / / \mathrm{www}$.altersummit.eu/accueil/article/fighting-cleaning-women-of-the-117

${ }^{7}$ http://www.wsj.com/articles/greeces-cleaners-win-back-jobs-in-defiance-of-austerity-1431351250 